\title{
Feasibility of Power Generation from MSW by Plasma Gasification Technology: A Case Study in Sri Lanka
}

\author{
UG Kithsiri, SKA Fernando, Lalith Srilal, PDSH Gunawardana, TSN Wimalasiri, \\ DS Jayawardena, Ruchira Abeyweera and NS Senanayake
}

The Open University of Sri Lanka, Nawala, Nugegoda Sri Lanka

\begin{abstract}
This paper presents the outcome of a study undertaken to determine energy harvesting potential of Municipal Solid Wastes (MSW) and, the feasibility of using Plasma assisted gasification process for electrical power generation. In this study quantitative and qualitative analysis of MSW were carried out considering the waste generated in the western province of Sri Lanka, encompassing three Districts; Colombo, Gampaha and Kalutara, to select the most feasible technology. Further, social, economic and ecological aspects of the selected technology are discussed together with sustainability of such an implementation.
\end{abstract}

Key words- MSW, Plasma Gasification, Sri Lanka

\section{Introduction}

Annual total waste generation in the world amounts approximately to 4 billion tons, whereas the annual solid waste generation in cities around the world is about 1.5 billion tons. This quantity is expected to increase to 2.4 billion tons by 2025. In lower income countries, waste generation will be more than doubled over the next 25 years. Three-fourth of this waste is disposed of in landfills, with only one fourth being recycled [1].

Municipal Solid Wastes (MSW) has become a very crucial issue with the steady increase of its generation in phase with economic and population growth, and Sri Lanka is no exception. Accumulation of MSW without a proper waste management strategy poses serious problems to the environment, especially to the health of urban people, as large amounts of MSW is frequently dumped in close proximity to residential areas. As far as Sri Lanka is concerned, the western province is the most affected due to accumulation of MSW for the obvious reason that the main commercial city, Colombo and the capital city Sri Jayewardenepura, being both located in the western province. MSW generation in Western province is about $60 \%$ of the total waste generation in the country [2].The main MSW generating sources in the province are households, commercial sector and business community. In addition, various industries and hospitals too, are responsible for contributing significantly to MSW of the province. The residential waste accounts for $55 \%$ to $65 \%$ of total MSW generation, while commercial, industrial and hospitals generate between $35 \%-45 \%$ in the province $[2,3]$.

One of the biomass waste disposal methods is gasification, which in turn is linked to the generation of electrical power. Power generation by gasification of biomass is a wellestablished technology worldwide, with different types of gasification technologies. MSW gasification is also a proven application for electricity generation, since it has a higher percentage of organic compounds. MSW-based power generation also provides a solution to environmental pollution caused by continuous accumulation of waste in the cities. In Sri Lanka, use of MSW for power generation has not been implemented yet as a solution to waste management, despite waste generation becoming unmanageable with no lands available for disposing the waste in the form of landfills.

\section{MSW in Western province}

Western province contributes around $60 \%$ of total waste generation and the amounts of collection are given in Table 1 [2]. 
Table 1 - Waste Generated/Collected in Western Province and in the County

\begin{tabular}{|l|c|c|}
\hline Area & $\begin{array}{c}\text { MSW } \\
\text { Generation } \\
\text { (Mt/Day) }\end{array}$ & $\begin{array}{c}\text { MSW } \\
\text { Collection } \\
\text { (Mt/Day) }\end{array}$ \\
\hline $\begin{array}{l}\text { Western } \\
\text { Province }\end{array}$ & $\begin{array}{c}3000-3500 \\
(60 \%)\end{array}$ & $2100(60 \%)$ \\
\hline $\begin{array}{l}\text { Colombo } \\
\text { District }\end{array}$ & $2000-2100$ & 1450 \\
\hline $\begin{array}{l}\text { Gampaha } \\
\text { District }\end{array}$ & $900-1000$ & 450 \\
\hline $\begin{array}{l}\text { Kalutara } \\
\text { District }\end{array}$ & $350-400$ & 170 \\
\hline $\begin{array}{l}\text { Whole } \\
\text { country }\end{array}$ & $6000-7000$ & $3600-4200$ \\
\hline
\end{tabular}

\section{Composition and Properties of MSW}

MSW in Sri Lanka comprises around 80\% biomass (organic) components and has an average lower heating value (LHV) of 9 $\mathrm{MJ} / \mathrm{kg}[2]$.

\section{Figure 1 - MSW Composition in Colombo, Sri Lanka [4]}

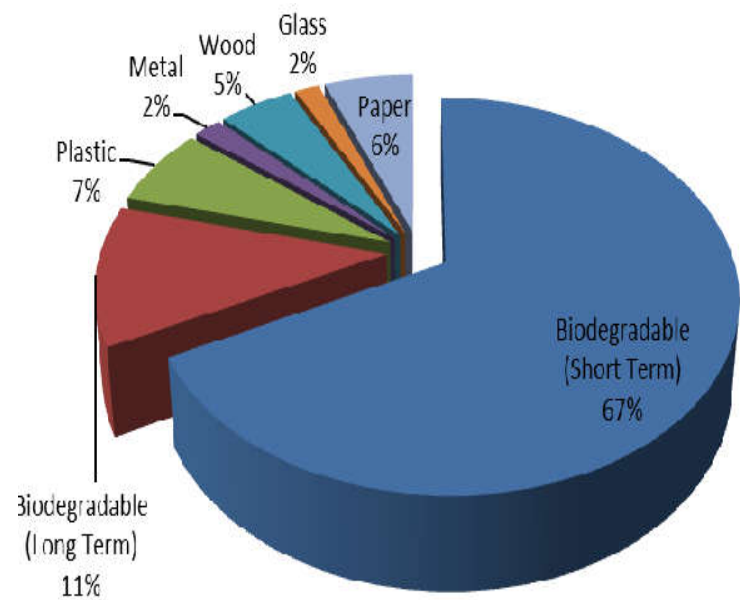

\section{Traditional MSW Treatment Methods}

The most traditional MSW management solution is the landfill. MSW collection, transportation, consolidation, and disposal of waste are the steps of this method. Apart from that, low temperature gasification and incineration are also practised to treat MSW. However, the unprecedented growth in MSW generation has caused the society at large to explore and implement alternatives to manage waste, to ensure a clean environment free from hazards, since traditional methods are totally insufficient to deal with the current problem. In this backdrop, technologically advanced methods have to be used to convert MSW to useful end-products.

\section{Low Temperature Gasification}

Gasification is a process that converts carbonaceous materials, such as coal, petroleum, or biomass, into a product gas comprising primarily of carbon monoxide and hydrogen, with lower amounts of methane, higher hydrocarbons, carbon dioxide, water vapour and nitrogen, depending on the gasification agent (oxidant) used. Air, oxygen, steam or a mixture of these are used as oxidants. Gasification involves thermochemical processes at temperatures above $700^{\circ} \mathrm{C}$. Feedstock requires some pre-processing to remove inorganic materials that cannot be gasified. After the gasification process, a cleaning process is required to obtain syngas with permissible levels of impurities. Clean syngas can be used in a boiler, IC engine or a gas turbine to generate electricity.

\section{Incineration}

MSW is used as a fuel in incineration process, burning it with high volumes of air. Typical combustion temperature inside an incinerator is $1000-1500^{\circ} \mathrm{C}$. The main output of incineration is the hot gas mainly with carbon dioxide and ash. Hot gasthus generated could be used to make steam in waste-to-heat plants, which is then used to generate electricity. Incineration reduces the waste volume by 80 $90 \%$. This process is primarily a method of waste disposal, converting waste to heat for power generation or process heat applications. It eliminates the leachate produced in landfills, and ash produced in the incineration process can be used in the construction industry. Capital requirement for incineration facility is high, and operation and maintenance costs are also considerably high. Smoke and ash emission to the atmosphere is a concern, which requires filtering and cleaning process to protect the air quality of the surroundings. Fly 
ash is also a serious problem in the incinerated waste as it contains significant amounts of toxins such as heavy metals.

\section{Plasma Assisted MSW Gasification}

Plasma is considered the fourth state of matter. The three other states are solid, liquid, and gas. It is a cloud of protons, neutrons and electrons where all the electrons have come loose from their respective molecules and atoms, giving the plasma the ability to act as a whole rather than as a bunch of atoms. Plasma is more like a gas than any of the other states of matter, because atoms are not in constant contact with each other, but it behaves differently from a gas. Plasma is formed due to electrical arc discharge passed through the gas. Plasma flame or arc generates a temperature of about 10,000F.This plasma arc is used for MSW gasification at very high temperature, which is usually 3,000F temperature $[5,6]$.

Municipal Solid Waste stock is exposed to the instant plasma heat inside a sealed aircontrolled reactor compartment. In this process reaction will initiate and reaction rate is elevated due to high heat energy of Plasma. In the reaction chamber, all the carbon based compounds convert into synthetic gases and inorganic parts get melted into sludge and poured out from the reactor bottom

\section{Figure 2 - Conversional to Plasma Gasification}

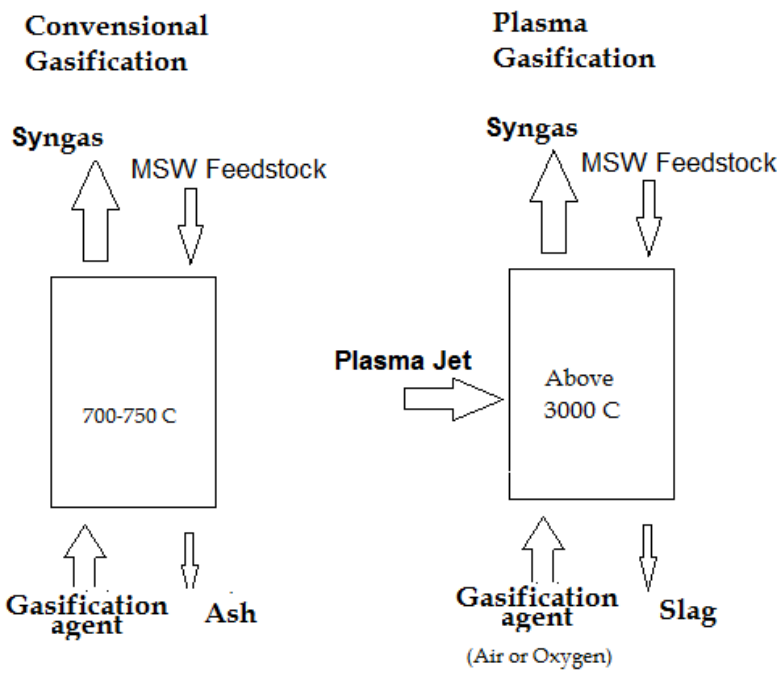

The most important concern is, due to high heat, all the hazard ousparts get destroyed during the process. Chemical reactions occurring inside the reactor are:

$$
\begin{aligned}
& \mathrm{CO}+\mathrm{H}_{2} \mathrm{O} \rightarrow \mathrm{CO}_{2} \uparrow+\mathrm{H}_{2} \uparrow \\
& 2 \mathrm{C}+\mathrm{O}_{2} \rightarrow 2 \mathrm{CO} \uparrow \\
& \mathrm{C}+\mathrm{CO}_{2} \rightarrow 2 \mathrm{CO} \uparrow \\
& \mathrm{C}+\mathrm{H}_{2} \mathrm{O} \rightarrow \mathrm{CO} \uparrow+\mathrm{H}_{2} \uparrow
\end{aligned}
$$

After all reaction states, finally heat energy, synthetic (gaseous fuels / $\mathrm{CO}$ and $\mathrm{H}_{2}$ ) gas and slag are generated as outputs [5, 7].

As shown in Figure 4, plasma gasification produces higher amounts of $\mathrm{CO}$ and $\mathrm{H}_{2}$ than those of the traditional gasification process. Also, this technology converts greenhouse gases such as methane $\left(\mathrm{CH}_{4}\right)$ into $\mathrm{CO}$ and $\mathrm{H}_{2}$. The clean synthetic gases produced can be used in IC engines and gas turbines for electrical power generation. Furthermore, this gas can be used to run steam turbine cycle and combined Brayton cycle and Rankine cycle, to generate electricity. 
Figure $3-\mathrm{H}_{2}$ to $\mathrm{CO}$ Ratio of Syngas of Traditional and Plasma Treatment

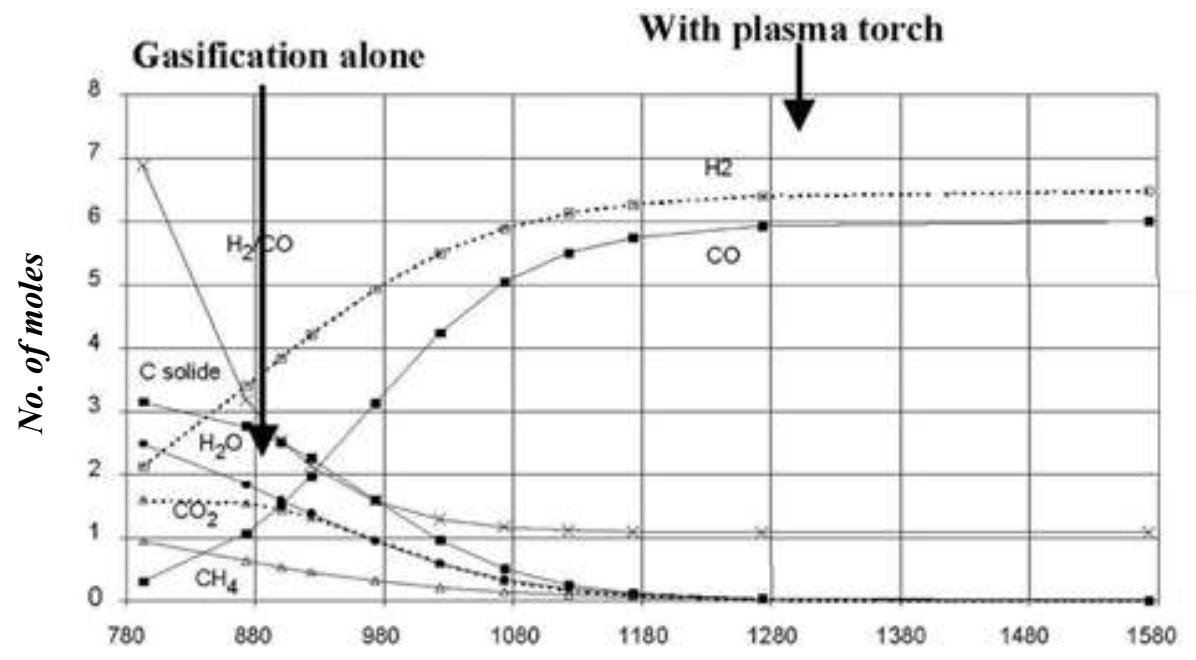

Temperature $\left({ }^{\circ} \mathrm{C}\right)$ Although traditional gasification is a proven technology to MSW management, plasma technology is more efficient than the traditional method in electrical power generation, owing to high temperature operation and higher conversion rate. Plasma gasification needs higher investments than the traditional method. However, due to high gain of the process and high feeding rate together with the fact that this technology provides a feasible solution to environmental problem caused due to MSW, plasma gasification is considered to be economically viable for long term.

When compared with incineration, the capital requirement for the plasma gasification is more similar to incineration technology. Plasma gasification is more efficient than incineration because inorganic residues (byproducts) can be used to manufacture bricks and concrete aggregate required for the construction industry. Furthermore, plasma gasification is $50 \%$ more efficient for power generation; hence it reduces the payback period $[6,7,8]$.

\section{Applicability of Plasma Assisted MSW Gasification in Sri Lanka}

\section{Technical Feasibility}

Plasma gasification of MSW has been developed in several institutions worldwide to produce electricity and it is a proven technology. Gasification integrated power plants (ex. gas turbines, combined cycle power plant etc.) have been installed in several countries [5]. World leading inventors and manufactures of power plants which use syngas fuel from plasma assisted MSW gasification technologies are; Westinghouse technology, In EnTec, Europlasma, and Plasco [5].

The performance of plants provided by leading manufactures mentioned above were compared to select the most feasible option for the present application. This comparison considered the gas turbine as a prime mover, and the calorific value of the MSW to be $10 \mathrm{MJ} / \mathrm{kg}$ (in Colombia) [5].

Table 2 - Comparison of Technologies [5]

\begin{tabular}{|l|c|}
\hline Technology & $\begin{array}{c}\text { Possible Power out } \\
\text { kWh/ton of MSW }\end{array}$ \\
\hline $\begin{array}{l}\text { Westinghouse } \\
\text { Technology(Alter nrg) }\end{array}$ & 617 \\
\hline In En Tec & 450 \\
\hline Europlasma & 500 \\
\hline Plasco & 530 \\
\hline
\end{tabular}

\section{Westinghouse Gasification Technology}

This technology was introduced by Westinghouse Plasma Corporation. Considering its high output power, this technology was selected to study. This helps to recover clean sustainable energy through plasma gasification. House hold wastes, industrial wastes and any type of biomass can be used as feedstock. Feed handling, gasification using plasma torch, gas cooling 
and cleaning up the gases are the main processes in this technology. Further, this does not want require MSW to be preheated, and can directly be fed into the gasifier.

Gasifier models listed below have been introduced by Westinghouse Plasma Corporation.

Table 3 - Comparison of Modes [9]

\begin{tabular}{|c|c|c|c|}
\hline Model & $\begin{array}{c}\text { MSW } \\
\text { Feeding } \\
\text { (tpd) }\end{array}$ & $\begin{array}{c}\text { Electricity } \\
\text { Generation } \\
\text { (MW) }\end{array}$ & $\begin{array}{c}\text { Fossil Fuel } \\
\text { Replacement } \\
\text { (bbl/y) }\end{array}$ \\
\hline P5 & $30-100$ & Up to 5 & 50,000 \\
\hline W15 & $100-290$ & Up to 15 & 150,000 \\
\hline G65 & $450-1000$ & Up to 50 & 650,000 \\
\hline
\end{tabular}

tpd: tone per day, bbl: barrel

According to the information in Table 4, the model of G65 which is capable of handling 450 to 1000 tonne/day of MSW and can generate up to 50MW of electrical power. Since the Western province of Sri Lanka has 2100 tonne/day of MSW, it is possible to introduce two units of G65.

Considering this product information and results from the study, the amount of power generation can be estimated as follows.

MSW collected = 2100 tonne $/$ day MSW consumption $=2000$ tonne $/$ day (Two G65 units)

Lower Heating Value of MSW $=9 \mathrm{MJ} / \mathrm{kg}[2]$

Energy harvesting potential

$=(617 \mathrm{kWh} /$ tonne $)(2000$ tonne $/$ day $)(0.9)$

$=1110.6 \mathrm{MWh} /$ day

Power generating capacity $=46.275 \mathrm{MW}$

This amount of power generation was estimated considering a heating value of 9 $\mathrm{MJ} / \mathrm{kg}$ of MSW in western province. The plant factor was considered to be unity. Therefore, the energy harvesting potential of MSW in the western province would be around the $46 \mathrm{MW}$, if Westing house Plasma gasification technology is used.

\section{Economic Feasibility}

Renewable energy projects are not always as financially attractive as electricity generation projects which use fossil fuels. Most of Sri Lanka's electricity generation and all transmission is done by Ceylon Electricity Board (CEB). Distribution is done by both Ceylon Electricity Board (CEB) and Lanka Electricity Company (Pvt) Limited (LECO) which is also a subsidiary of CEB. Public Utilities Commission in Sri Lanka (PUCSL) was formed as a regulatory body to regulate tariffs. Following is the latest tariff announced by PUCSL for purchases of electricity from Non-Conventional Renewable Energy (NCRE) projects.

Table 4 - Flat Tariff [10]

\begin{tabular}{|l|c|}
\hline Technology & $\begin{array}{c}\text { All-inclusive rate } \\
\text { (LKR/kWh) for year } \\
\mathbf{1 - 2 0}\end{array}$ \\
\hline Mini-hydro & 16.70 \\
\hline Mini-hydro-local & 17.15 \\
\hline Wind & 20.62 \\
\hline Wind-local & 21.22 \\
\hline Biomass (Dendro) & 25.09 \\
\hline $\begin{array}{l}\text { Biomass (Agricultural \& } \\
\text { Industrial Waste) }\end{array}$ & 17.71 \\
\hline Municipal Solid Waste & 26.10 \\
\hline Waste Heat & 9.19 \\
\hline
\end{tabular}

The fixed rates shown in the Table 5 will not be escalated for any reason during the 20 year time frame.

The tariff is cost-based and technology specific and most importantly, the developer has the right to choose the above tariffs and a three tier tariff, based on their requirements. Standardized power purchase agreement (SPPA) is a 20 year agreement between the developer and CEB (who is purchasing the generated power) and the above rates are applicable for such SPPAs with a rated capacity below 10MW. It is also to be noted that the highest feed in tariff is assigned for power generation using MSW due to the fact that the technology is not as matured as any other form of NCRE technologies and to encourage developers to focus on such new power generation alternatives. 
Table 5 - Three-tier Tariff [10]

\begin{tabular}{|c|c|c|c|c|c|c|}
\hline \multirow[b]{2}{*}{ Technology / Source } & \multicolumn{2}{|c|}{ Escapable Base Rate } & \multicolumn{3}{|c|}{ Fixed Rate } & \multirow{2}{*}{$\begin{array}{l}\text { Royalty to Govt. } \\
\text { (\% of total Tariff) } \\
\text { Year } 16-20\end{array}$} \\
\hline & $\begin{array}{c}\text { O\&M } \\
\text { (year 1-20) }\end{array}$ & $\begin{array}{c}\text { Fuel } \\
\text { (year 1-20) }\end{array}$ & $\begin{array}{c}\text { Year } \\
1-8\end{array}$ & $\begin{array}{l}\text { Year } \\
9-15\end{array}$ & $\begin{array}{l}\text { Year } \\
16-20\end{array}$ & \\
\hline Mini-hydro & 1.93 & None & 16.81 & 6.38 & 5.80 & $10 \%$ \\
\hline Mini-hydro-local & 1.98 & None & 17.27 & 6.55 & 5.95 & $10 \%$ \\
\hline Wind & 1.30 & None & 22.63 & 8.58 & 7.80 & $10 \%$ \\
\hline Wind-local & 1.34 & None & 23.29 & 8.83 & 8.03 & $10 \%$ \\
\hline Biomass (Dendro) & $\begin{array}{c}1.50 \text { (1-15 years) } \\
1.88 \text { (16-20 years) }\end{array}$ & 12.25 & 9.8 & 3.72 & 3.38 & None \\
\hline $\begin{array}{l}\text { Biomass (Agricultural \& } \\
\text { Industrial Waste) }\end{array}$ & $\begin{array}{c}1.50 \text { ( } 1-15 \text { years }) \\
1.88 \text { ( } 16-20 \text { years })\end{array}$ & 6.13 & 9.8 & 3.72 & 3.38 & None \\
\hline Municipal Solid Waste & 5.31 & 1.75 & 19.8 & 7.51 & 6.83 & None \\
\hline Waste Heat & 0.52 & None & 10.19 & 3.86 & 3.51 & None \\
\hline
\end{tabular}

\section{Financial Model}

The financial model was formulated with the objective of presenting the financial viability of the project. Following indicators are calculated to show the viability of this technology in financial terms.

Internal Rate of Return (IRR)

Net present value of the project (NPV)

Simple Payback Period

\section{Assumptions:}

The financial model was developed based on the following assumptions;

- Debt interest rate would be $3.5 \%$ with a settlement period of 8 years and the applicable tax component;

- Cost of equity of the firm would be $21 \%$

- Port and Airport Development Levy (PAL) would be $5 \%$ throughout the project period.

- Corporate Tax Rate (income tax on projects) would be $17.5 \%$ with a tax holiday of 10 years.

- Project insurance premium is considered as $0.05 \%$ per annum

- Tariff would be $26.10 \mathrm{LKR} / \mathrm{kWh}$ for the project period

\section{Revenue Forecast:}

Annual energy yield is shown below.

- Plant Capacity:50 MW

- Annual Energy Yield (P50):366.498 GW

- Plant Factor: 83.68\%

\section{Investment:}

The initial investment was considered based on the literature findings as mentioned below [5].

-WTE Plant

USD 534.6 million

- IGCC Plant USD 72.6 million

- Total Investment USD 607.2 million

\section{Sources of Finance:}

The initial investment was analyzed in the following manner to make the return on equity further enhanced. Owner equity investment would be $30 \%$ of the total project cost and the rest of the required funding would be provided as a bank loan. This combination will lead the project to be a $70 \%$ geared company.

Project Cost 607.2 million USD

Equity Ratio $\quad 30 \%$

Debt Ratio $\quad 70 \%$

Equity Amount $\quad 182.2$ million USD

Loan Amount $\quad 425.0$ million USD 


\section{Cash Flow Analysis:}

Weighted average cost of capital (WACC) was considered as $5.6 \%$, and the same was used as the discount rate to appraise the project against the baseline scenario. Sale of electricity was considered as the main source of income, while two other additional sources were also identified to maintain a healthy cash flow throughout the project life time. Carbon trading, which is a result of the clean development mechanism (CDM) was considered as the second revenue generating mechanism with an average cost of USD 3.8 /tonne- $\mathrm{CO}_{2}$ (eq). The third income source is not in practice at the moment in the country but would be a proposal made to the government by the developer since the project uses MSW as the fuel for power generation which eases problems of handling and dumping of MSW. The proposed rate is USD 5 per tonne of MSW which is reasonable compared with the actual cost of handling and dumping of MSW. A 20-year planning window was used to appraise the project to measure the financial viability of the investment. Net Present Value (NPV) was calculated for the 20-year period to determine the overall project feasibility and showed a negative value, indicating that the investment is not viable from an investor's point of view. Project and equity Internal Rate of Return (IRR) were $3.95 \%$ and $4.11 \%$ respectively. The cumulative cash flow was determined and break-even was found to be 13 years.

\section{Ecological Feasibility}

Volume reduction of the MSW after plasma gasification is significant and has been proven to be more than $95 \%$. Table 6 shows the $\mathrm{CO}_{2}$ emission per $\mathrm{MWh}$ power generation compared with other power generation processes. It is clear that MSW Plasma Gasification shows low $\mathrm{CO} 2$ emissions.
Table $6-\mathrm{CO}_{2}$ Emission [8]

\begin{tabular}{|l|c|}
\hline $\begin{array}{c}\text { Power Generation } \\
\text { Process }\end{array}$ & $\begin{array}{c}\text { Pounds of } \mathbf{C O}_{2} \\
\text { Emission/MWh }\end{array}$ \\
\hline MSW Incineration & 2,988 \\
\hline MSW Plasma & 1,419 \\
\hline Coal & 2,249 \\
\hline Natural Gas & 1,135 \\
\hline Oil & 1,672 \\
\hline
\end{tabular}

Inside temperature of the furnace of plasma gasification process is above $3000{ }^{\circ} \mathrm{C}$ and organic materials are converted to syngas of $\mathrm{H}_{2}, \mathrm{CO}_{2}$, and $\mathrm{CO}$. Inorganic materials are converted to solid slag and toxic compound in the slag below the recommended level. Exhaust after the gas turbine or boiler release into atmosphere under the specified temperature range. This in turn will reduce the environmental issues of MSW, and in return it will reduce air pollution, land pollution, flood, landfills and visual pollution.

\section{Social Aspects of Plasma Assisted MSW}

Pollution reduction will directly address health issues of the nearby community. Clear environment creates validity for lives and properties, and increase the social development index. These projects also create many opportunities for several job layers with different skills and expertise, and reduce unemployment.

A large section of population living in nearby landfills suffer from infectious and contagious diseases due to the polluted water bodies and landfills. Setting priorities in MSW management through plasma gasification to energy recovery could reduce the negative impacts of waste to a large extent, and improve the hygienic conditions of the community. This will have an overall positive impact on the health conditions of the community.

\section{Technical Feasibility}

Synthetic fuel gas or syngas is a low calorific value fuel produced from gasification process. Modification of an existing fossil fuel fired power plant into a syngas driven power plant 
is possible. This modification includes wider fuel flow path to increase gas flow into combustor since it has lower heating value [11]. It is also required to couple the air extractor to the compressor for control of inlet air flow. Syngas in crude stage is very dirty and consists of chemicals harmful to turbine blades; hence a syngas treatment unit has to be installed to purify the gases [12]. This modification may not be economical. However, since the government has already declared projects to covert fossil fuel plants into natural gas plants [13], during this conversion projects, modifications for syngas could also be introduced. In these projects, gasifier and gas treatment unit need to be installed separately. Either syngas or natural gas is possible to be used as a fuel by adjusting air to fuel ratios. Also there is a possibility of mixing of natural gas with syngas, which is a proven technology, to generate power. Installation of a new plant is a second option where it could be an integrated gasification combined cycle (IGCC) power plant consisting of a gas treatment unit and other auxiliaries.

\section{Conclusion}

Solid waste management is one of the major social and environmental requirements in Sri Lanka. In developing countries such as Sri Lanka, owing to poor waste management, policy and economic concerns, it has become a major issue on a national scale. Western Province is the most diversified, populated economic center of the country, which suffers from poor waste management for the past few decades. Owing to rapid development of urban cities in the western province, population density is very high.

In Sri Lanka most of the collected Municipal Solid Waste end up in open dumping yards located near the cities and in open burning, which cause air pollution. In some cases like toxic chemicals, are deposited in illegal dumping sites. This type of open dumping, open air burning and illegal dumping yards cause many short term and long term social and environmental problems. The highest percentage of MSW is for short term bio degradable wastes such as food and plant residues. The second highest percentage is plastics, shopping bags and polythene-based materials. In total, around $80 \%$ of MSW contains combustible biomass. Furthermore, it has been estimated that the heating value of MSW available in the western province is around $9 \mathrm{MJ} / \mathrm{kg}$. MSW collected in the western province of Sri Lanka is 2100 tonne per day and thus MSW in the selected area has a potential to generate around46MW through plasma gasification.

The Westinghouse plasma gasification technology was identified as the most sustainable technology after comparison with other plasma gasification technologies available.

Moreover, the government has established a new development plan based on the western province and according to that, all thermal power plants are expected to be replaced by Liquefied Natural Gas (LNG) and similar substances. In that case, the developer has the option of using the IGCC plant to plug into the Waste to Energy (WTE) system and the initial investment would then be reduced to USD 534.6[5] and the project IRR would be improved to $5.10 \%$.

There is no doubt regarding socio-ecological sustainability but less economic sustainability with high capital investment on the gasifier module and gas turbine power plant. Considering socio-ecological benefits given by this solution, it is suitable to implement such a system in the western province. In the long term, it will bring more economical benefits also by reduction of expenditure on health, and proper valuation of assets near the dumping yards. Social development will uphold the economy and the overall development of the country. Finally green energy using plasma gasification would be a sustainable solution for the western province of Sri Lanka under to manage the MSW. 


\section{References}

[1] Gasification waste to energy technology, http://www.gasification-

syngas.org/uploads/downloads/GTC_Waste_to_Ene rgy.pdf

[2] Western province waste Management Authority, Sri

Lankahttp://www.wmawp.lk/sn/admin/userfiles/files /Pre\%20Bid\%20UDA.pdf

[3] A,Mountouris, E. Voutsas, D. Tassios, Solid waste plasma gasification: Equilibrium model development and $e$ energy analysis, School of Chemical Engineering, National Technical University of Athens, October 2005

[4] J.NilanthiJ, G. J. Bandara, Municipal Solid Waste Management, The Sri Lankan Case, University of Sri Jayewardenepura, Sri Lanka.

[5] D.Caroline, Prof.J.Nickolas, Prof.J.Marco, Technical and economic analysis of Plasma-assisted Waste- toEnergy processes, Columbia University.

[6] Atlantic County Bio-Energy Facility, ACUA \& NRG Partnership, December 3, 2010

[7] Qinglin Zhang, Mathematical modeling of municipal solid waste plasma gasification in a fixedbed melting reactor, Doctoral Dissertation, Royal Institute Technology, Stockholm 2011

[8] P.M.Lal, C.J.Singh, Plasma Gasification: A Sustainable Solution for the Municipal Solid Waste Management in the State of Madhya Pradesh, India, International Journal of Environmental Sciences Vol. 3, No 1, 2012

[9] Westinghouse Plasma gasification flyer by Westinghouse Plasma Corporation http://www.alternrg.com/waste_to_energy, www.westinghouse-plasma.com/

[10] http://www.pucsl.gov.lk/english/ notices/feed-in-tariffs-2012-2013/

[11] Gas Turbine ModernizationFuel Conversion and Special Fuel Applications, www.siemens.com/energy

[12] Dr. G. C. Young, Municipal Solid Waste to Energy Conversion Processes; Economic,Technical and Renewable Comparisons

[13] Master Plan of Western Province Mega Polis Development,Sri

Lanka.http://www.megapolis.gov.lk/downloads.php

[14] K.Gonawala, A.Parmar, M.Mehta, Plasma Gasification of Municipal Solid Waste: A Review, International journal of engineering sciences $\mathcal{E}$ research technology

[15] Qinglin Zhang, LiranDor, Lan Zhang, Weihong Yang, WlodzimierzBlasiak, Performance analysis of municipal solid waste gasification with steam in a Plasma Gasification Melting reactor
[16] V.E. Popov,A.Bratsev, V.A.Kuznetsov, S.V.Shtengeland A.A. Ufimtsev, Plasma gasification of waste as a method of energy saving, Institute for Electro-physics and Electric Power RAS, Russia

[17] L.Tang, H. Huang, H.Hao, K.Zhao, Development of plasmapyrolysis/gasification systems for energy efficient and environmentally sound waste disposal, Guangzhou University, China 